\title{
The Actualization of Woman Empowerment In Islamic Economy
}

\author{
Sumar'in Asmawi* \\ Sultan Muhammad Syafiuddin Institute of Islamic Studies of Sambas, Indonesia \\ Iwan Kusnadi \\ Sultan Muhammad Syafiuddin Institute of Islamic Studies of Sambas, Indonesia
}

\begin{abstract}
Islam really appreciates the dignity, the prestige, and the woman's right, without the different to the man. The mowan's moval in today context is the moval which has value, meaning and the potential itself. The woman empowerment program to the woven fabric craftsman which have been done in Sumber Harapan village, Sambas regency is the real woman self-actualization in Indonesia. The research is a field research. The technique of data collecting is observation, interview and documentation. The analysis technique in this research is analysis model interactive and SWOT analysis. According to the data analysis and explanations that the strategy of woman empowerment reinforcement to the woven fabric craftsman in Sumber Harapan village, Sambas regency include: 1). Increase the product intensification and diversification. 2). The utilization of work ethic to expanding the access of market. 3) the integrated founding and development to increase the quality of human resources. 4). Utilize the government supports and the private to consolidate the financing in increasing the means and the infrastructure. 5) Increase the cooperation with the competent institution .
\end{abstract}

Keywords : islam, women, and empowerment

\section{INTRODUCTION}

Islam is a perfect religion manage the human's life context in detail. One of the basic value in Islam is admitting the similarity of human being in front of Allah Swt without seeing the difference. Whether it is the difference in race, generation and gender. The measurement and the standard in Islam is the level of godfearing to Allah Swt. Islam has unique position due to admitting the independent economy status of women and give the right to be possesed of something, using and enjoying it without mediator or guardian (Qutub, 2001).

\footnotetext{
*E-mail : sumarinfebi@gmail.com

Received : 27-9-2018, Accepted : 9-10-2018, Published : 30-12-2018

P-ISSN : 2087 - 9954, E-ISSN : 2550 - 0066. DOI:http://dx.doi.org/10.26418/jebik.v7i3.28301
} 
Islam really appreciates the dignity, the prestige, and the woman's right, without the different to the man. The women are free to develop her economy and cannot be marginalized. Moreover, Islam gives the chance to the women to run their role totally. In Islam principle, the men and women responsibility are same. Everyone who done the good deed, men or women, while he/she in his/her faith, so he/she will get the heaven. The highest of good deed which can be reached by the men, so do the women.

Women's moval today is the moval which has value, meaning and potential. It is including many factors in the society and one of them is effort and wome's strength in increasing life level in society. Based on Education for All (EFA) and Millenium Development Goals (MDGs) who support the gender equality and empowering the women by decrease the difference and gender discrimination in all life aspects, consider important to do. The problem relates to the discrimination need an attention from the government and all of society soon need a solution.

Refer to the Law number 7 on 1984, relates about Convention on the Elimination of All forms of Discrimination Against Women (CEDAW) should become the law shield and maintain the discrimination to the women. More over based on the understanding in the CEDAW, stated that the country join in CEDAW must change the national law in order to remove the discrimination to the women and protect the women's right, include in Indonesia as one of the country in CEDAW. However, until today the thought of in society and their deed still marginalized. Even, in this modern era, the women reputed as an "object" in a household.

The problem often faced in applying the job vacancy is not easy as faced by the men. There is an opinion that women's life is enough if she is busy with the things just in the house. Automatically, she has no much time to enrich their knowledge or making money for their family (Dellyana, 2004). Being ironic, according to civil census (Sensus Penduduk) in 2010. The comparison of men $50.17 \%$ and women $49.83 \%$, means that almost ten of the total number of Indonesian is not productive. The big number of Indonesian women is about same with the total number of Indonesian men and of course have a big influencev in developing the economy should be optimized.

Refers to Basuki's \& Prasetyo's (2007) opinion shows that the women is the management key of family economy due to much of women's influence as: first, as family financial management; second, take responsible in whole domestic works; third, as family money maker; and fourth, as one of important social network bond in social transfer, esspecially in critical and crisis time. Asiya's (2017) research explained that reality showed, women have independent and leadership level when she trusted as chief of family. It is as seen as when a family left by the men, so the women still stay exist, work for the family. The research shows that the women as a chief of a family and stay alone has $31.60 \%$ productivity, higher and bigger if compared to the men as chief of a family and live alone has 3.53\%. Then the next research who has been done by Sahran (2009) stated that the chance and the equality of women to a men, make the women 
actualize herself and develop their potential that they have. Not only experience and skill development reached by the women, more than that. The woman can be trusted as a leader (Sahran, 2009).

The other research has done by Haryanto (2012) also explained that the women's role in increasing the family income. Based on the research, the income that the women got by the women as bricklayer felt enough to fulfill life need for $73.33 \%$. In that case, the contribution of women worker to her husband's income is significant enough. In utility, the income can be used to fulfill daily needs, school need and social needs.

According to Marwanti, S \& Astuti (2012), three important reasons why women must empowered in the context of fighting poverty, there are: (1) because women have the same importance in development, and also as a user of development result which have the same rights to the men; (2) women also have the same importance especially to the women and children, the less optimal if men face it because it needs sensitivity in a specific way, relates to the daily life, sosiocultural; and (3) empowering and involving the women in development, automatically will also empowering and giving the positive spirit to the next generation which generally so tight to the figure of a mother.

The assumption from some of previous researches explained that women empowerement in increasing the family economy potential is very important to be optimized. In the context of national development, the women development means effort to growing up the potential and woman's role in all life aspect. Stated that one of the purpose of the woman empowerement program is increasing the women capability in managing trade, in the scale of family, whether the small or big industry to support the raising of the need of household or to opening the chance productive and independent works.

The society empowerement in essence is the effort to increasing the dignity of society particularly in today where many people can not lose from the trap of poverty and the backwardness. Means that the empowerement help the people to find the capability to be independent. Empowerement in economy is an effort to develop the people power by supporting, motivating and arousing the awareness of economy potential that they have and develop it. The people power is the basic element of the people to survive.

In dynamic explanation is developing and reach the progression. People power become a source on what we known as national survive (Mubyarto, 1997). The women empowerement program in family life will be an entrance to improving the family prosperity. Related to improving the family prosperity indirectly empowering the women to stand their family's economy. The condition is the big support for the women to work in increase the income. As the women empowerement program to the woven fabric craftsman have been done in Sumber Harapan village, Sambas regency. The women empowerment esspecially to the woven fabric craftsman in this village is done by many 
people such as region government through Dinas Koperasi, UMKM, Perindustrian dan Perdagangan (Kumindag), Dompet Ummat and PT. Garuda Indonesia by giving many kinds of trainings, guiding the effort, and funding to the craftsman. The empowerement program is funded by many sources such as from the fund of Sambas regency APBD, CSR company, and productive zakat from the people. The empowerement program is prioritized to developing home industry especially to the woven fabric craftsman that managed by the society.

From the background above, the problem in this research is how is the strategy of developing the women empowerement to the woven fabric craftsman in Sambas regency? The problem is important and need a solution in order to increasing the people prosperity in the process of society economy empowerement, especially to the woven fabric craftsman which dominated by the women.

\section{LITERATURE REVIEW}

\subsection{Gender in Islam}

The term of Gender is a concept that known as western culture. The western is one of the civilization conquering and dominating the world declared itself as the civilization that equalize the gender (Cyril E. Black., Jonathan E. Helmreich., Paul C. Helmreich., Charles P. Issawi., 1992). Refering to the meaning, gender comes from English which means "sex". In the glossary called as sex and gender. As a definition, gender means as "a character close to the men and women constructed in social life. The cultural context or social relation which constructed between men and women absolutely depend on the problem of culture, religion, history and economy (Mufidah, 2010)" However there is significant difference among the western concept and Islam about gender, in the comprehension of feminism being a housewife is like a jail for a women to develop themselves. They think that a housewife is a left behind women, an inferior creature and suffer (Wolf, 1997). Feminism, as a soul of women's moval, can be explained as "an awareness towards suppresion and exploitation to the women in a society, in the work place, and in a family, also the awareness action whether by the women and men to change the condition (Khan, 1995).

While in Islam, a woman being a wife is fair of a husband in the family they complete each other. Without women, human's life will face destruction (Ar-Risalah, 2005). A wife has right and duty. One of them is taking care for the household (Abdullah, 2001). Islam also glorify the women (wives) where Allah create them as the sign of His mercy. More over according to Yuhanar Ilyas, the gender moval in Islam must have the awareness to gender inequalities, and should be based on value of Islam fundamental (Ilyas, 1997).

In general, Al Qur'an gives the high place to the women. On of the formal proof can be seen in al-Qu'ran. There is one surah which given a women name, that is al-Nisa'. 
Beside that, some of the other surah also talking about the women from some views and the main point is giving the positive appreciation. Islam place the women in the society, the truth is helping the family in reach the prosperity. In the other words, the women's role through empowerement is helping the husband in fulfill the family economy with the spirit of helping in the wellness. In the al-Qur'an, in surah at Tauba,verse 71, Allah SWT explains that the men and women are the creature that created to help and complete each other.

Of The women participation as a wife can be seen as a shape of a responsibility to the economy and social function a housewife in the society living. While if we stay concern from religion aspect, by quoting the writing of Mahmudi (2009) stated that the theory with qath'i characterized is the theory has principle character and universal especially talking about the freedom and individual responsibility. It is explain that Islam is the religion so glorify and respect the women without ignoring their role as a human to share and do something to help family economy.

\subsection{Women and the Empowerement the Economy of people}

Empowering the economy of people means developing the economy system from people by the people and also for the people importance. It is also increasing the people capability totally by developing and dynamic the potential. Women as part of Islam economy development is really admitted by the role and its function in empowerement of family economy. The women's role in the economy empowerement can be seen in the management.

According to Mulkhan (Amin Abdullah, 2000), that actually in economy, Islam's thought so potential to placed as a paradigm model of rational expectation about the future more oriented to the humanity. Social risk about injustice, imbalance, and poverty become a basic of appearing the humanity awareness of the economy and politic doers. It means the development in Islam economy concept should not be discriminate the current gender and regard as superior the others. This is become a confirmation that Islam really support the progression to the women.

The effort in leading the source to developing the people economy potential whether to the men and women keep optimize and synergy. Economy empowerement can be seen from three sides (Mubyarto, 1997): 1). Create the atmosphere and climate which is possible the people potential is develop. The starting point of the thought is introduction that every human, and every people, have the potential that can be developed, there is no people that have no power at all ; 2). Strengthen the economy potential that people have. Strengthen the ecomomy potential, the main effort is increase the education level, standard of healthy, and there is a big chance to wielding the economy opportunity ; 3). Developing people economy also means protect the people and prevent the imbalance rivalry and prevent the exploitation of high level economy to 
the low level. The effort to protect the people is in order to empowerement and development the initiative.

Through the real steps must be done in order to make the growing of people economy running fast. The strategy centered in effort to support the acceleration of structural changing which can strengthen the position and role of people economy in national economy. Empowering the people economy in reasonable way as same as empowerement the people economy. Therefore, no wonder if the people economy empowerement aspect become a theme central to the economy development. The growth of economy must show to justice emendation. The justice aspect must be translated in economy concept and political accepted (Abimanyu, 2000).

The empowerement of people economy actually consists of three missions. First, the development of business and economy is oriented to the measures of economy and business in common and universal. For instance, the production quantity, job demand, profit, saving, investment, export-import, and the progression of effort. Second, the implementation of ethic and the regulation of sharia law that must become the characteristic of economy activity of muslim. Third, developing the strength of muslim economy until become a benefactor for Islam socialization that can be taken through zakat, infak, sadaqah, wakaf and take part in the pillar of economy (Rahardjo, 1999).

The economy approach in the conventional theory during the year is not yet considering the benefit of the development dispassionately to the women and men also giving the contribution in appearing inequality and gender injustice. According to Marwanti, the women empowerement consists of three things (Marwanti, S \& Astuti, 2012) : (1) capacity building means developing the women capability; (2) cultural change is the changing of culture that lead to the women; and (3) structural adjustment is the structural adaptation lead to the women. The effort of empowerement is leaded to reach the prosperity of society through the gender equality. Furthermore, the model of women empowerement in the research become an analysis tool in answering the research problem. There are five criteria of analysis: (1) prosperity; (2) access; (3) awareness; (4) participation; and (5) control.

The simplicity of prosperity dimension can be measured by fulfilling the basic needs such as food, health, housing, as far as can be enjoyed by the women and men. The access and control dimension to the source appointing the men and women have chance and can make the decision on production source, have access and control on source such as land, worker, credit, information and skill. The asymmetry between men and women in source effecting the men and women productivity is different. The awareness dimension or the critical awareness emphasized to the need of critical awareness effort that the gender asymmetry happened caused of an assumption that the women social economy position is lower than men. The awareness means emergence of critical attitude. The next dimension is participation. In the development, the gender asymmetry in participation shown by not represented the lowborn lookslike elite institutions. 


\section{METHODOLOGY}

The research is kind of a field research (Nawawi \& Martini, 1996). The main data source is discovered through interview and polling spreading with the informans. The informan choosen by purposive sampling, means that the choosing of the informan is choosen by intentional based on subject that conquering the problem related to research focus and ready to give the data. The technique of collecting data is using observation, interview and document. The technique of collecting data in the research is using analysis model interactive and SWOT analysis.

The SWOT analysis is one of the analysis method that can be used to fomulate the strategy alternative based on internal and external condition. By using the SWOT analysis will require some of strategy alternative which have relavance among alternative (Rangkuti, 2003). The required alternative need to loaded due to the level of importance from each different alternative. Analytical Network Process (ANP) method is one of the Multi Criteria Decision Making (MCDM) method that can be used to arrange the importance priority from many available alternatives. Thus, the correct strategy alternative can be required and can be used for the gender actualization reinforcement in the empowerement of people economy. A case study to woven fabric craftsman in Sambas regency.

\section{RESULT AND DISCUSSION}

\subsection{The Social Condition of People}

Sumber Harapan village is one of the village in Sambas regency with the total number of people coming at 2.766 and the village area is $2.256 \mathrm{~km}^{2}$ with majority of people are Malay by the percentage reach to $95 \%$ followed by Tionghoa is $5 \%$. There are 95\% muslim, $2.5 \%$ is Khong $\mathrm{Hu} \mathrm{Cu}$ and $2.5 \%$ is Christian. Related to the culture, the people of Sumber Harapan village live as Sambas malay in general. The culture is influenced by Islam culture, especially by Islam Malay because of the local custom is so consistent followed by the people. For instance Zikir Nazam or Zikir Maulud in birth celebration, or wedding party. Even in the daily life such as the wedding party still using the traditional of Malay culture.

The economy rotation in Sumber Harapan village is low. It is happened because there is no support from Pasar Desa yet, so the economy access and the money rotation need to find to the other place especially around the Sambas city. In fulfilling the daily needs, people buy the things in small shop in every village. In general, means and infrastructur in the village is not enough, so the means and infrastructur really needed by the people.

Means and infrastructur transportation in the Sumber Harapan village consists of $65 \%$ by land and $35 \%$ by water. Due to the water traffic is big enough, so there are many piers. There are seven piers spreading along the river. The water transportation means are 
often used by the people is boat and motor boat. There are 215 boats in the village, and there are 19 motor boats. While in general the means that used as transportation tool are 9 motor boats. In the land traffic, the length of the main street is about $4.6 \mathrm{~km}$ and $100 \%$ is already asphalt pavement with the \pm 3 meters width street. There are some various of people's job such as farmer, craftsman, and labor. However, there is an economy icon really interesting in the village, that is Tenun Songket craftsman. Sambas woven fabric has already known whether in scale of national and international. The woven fabric is coming from this village.

Sambas woven fabric which usually called as "kain Lunggi" or "Kain Benang Emas". It called as gold woven fabric due to one of the material used is gold thread with coloured gold yellow. The gold thread of woven fabric still done in traditional way with spinning wheel made of very hard wood. Most of the work is done by the people around the Sambas river. The weavers are unique because of their skill in weaving is got from their parents or the skill is being taught for generations, not in a formal education.

Today, the fabric is still exist, even the people from another country is caught their eyes to Sambas woven fabric. The house of woven fabric is always welcoming the visitor that love woven fabric because of the uniqueness and the interesting design and pattern. The uniqueness in the woven fabric is the prominent design of pucuk rebung, decorated with design of spread flower and animal. The role of region government is very important for the growth of village economy. Until today, the region government has created the cooperative that works in craftsman, that is songket woven fabric. The cooperative named Koperasi Rantai Mawar. On 2016, the government has made Lumbung Tenun, which the function is provide a place for the woven craftsman. The women house production also built on 2016.

The development and the empowerement of Sambas woven fabric craftsman in the environment of people of Sumber Harapan village actually has been done by region government through Dinas Koperasi, UMKM, Perindustrian and Perdagangan (Kumindag) gave many trainings: the dye of hard-silk thread training, sewing various bag training, and many other trainings which the material is songket woven. The financial capital also given to the people such as Dompet Ummat program, the financial capital from PT. Garuda Indonesia.

\subsection{Discussion and Analysis}

The weaver is dominated by the women muslim that called as influential one in effort to support the progression od Sumber Harapan village to move the village economy. In the case, many people dedicate and depend on their life in this work. Based on the data from the village government, the number of woven fabric craftsman in Sumber Harapan village from time to time is increased. By the end of 2017, the result of 
survey from village government shows that the number of weaver in Sumber Harapan village are 277 people with 432 units of the woven tool production .

The encouragement and support from the region government, whether from the PT.Garuda Indonesia, Dompet Ummat Foundation and the others reputed support the progression of woven activity in Sumber Harapan village. It can be seen that the activity is develop and the number of weaver is increase. Based on the result of interview with the weaver also explain that the successful today is also helped by the promotion and the guidance from all people and institution take part.

Moreover, the number of Sambas songket woven fabric craftsman in Sumber Harapan village displayed in the list below:

List 1. The data of Sambas Songket Woven Fabric Sumber Harapan Village 2017

\begin{tabular}{|c|c|c|c|c|c|}
\hline \multirow[b]{2}{*}{ No. } & \multirow[b]{2}{*}{ Address } & \multirow[b]{2}{*}{ The craftsman } & \multicolumn{3}{|c|}{ MITRA BINAAN } \\
\hline & & & Tools & PT.GARUDA & $\begin{array}{c}\text { D.U } \\
\text { Foundation }\end{array}$ \\
\hline & & 1 & 8 & 9 & 10 \\
\hline I & $\begin{array}{l}\text { DUSUN SEMBERANG } \\
\text { I }\end{array}$ & & & & \\
\hline 1. & RT.01 /RW.01 & 34 people & 38 Units & 1 people & 2 people \\
\hline 2. & RT.02 /RW.01 & 18 people & 19 Units & 1 people & 2 people \\
\hline 3. & RT.03 /RW.01 & 35 people & 149 Units & 4 people & 2 people \\
\hline 4. & RT.04 /RW.02 & 14 people & 19 Units & - & - \\
\hline 5. & RT.05 /RW.02 & 29 people & 30 Units & 5 people & 2 people \\
\hline 6. & RT.06 /RW.02 & 16 people & 30 Units & 3 people & 2 people \\
\hline II & $\begin{array}{l}\text { DUSUN SEMBERANG } \\
\text { II }\end{array}$ & & & & \\
\hline 1. & RT. 07 RW.03 & 35 people & 38 Units & 3 people & 2 people \\
\hline 2. & RT. 08 RW.03 & 30 people & 46 units & 7 people & 3 people \\
\hline III & $\begin{array}{l}\text { DUSUN SULOR } \\
\text { MEDAN }\end{array}$ & & & & \\
\hline 1. & RT.09/RW.04 & 10 people & 10 Units & - & 2 people \\
\hline 2. & RT.10 /RW.04 & 17 people & 17 Units & - & 2 people \\
\hline 3. & RT.11/RW.04 & 8 people & 6 Units & - & 1 people \\
\hline 4. & RT.12/RW.05 & 17 people & 16 Units & - & - \\
\hline 5. & RT.13 /RW.05 & 14 people & 14 Units & - & - \\
\hline & TOTAL & 277 people & 432 Units & 24 people & 20 people \\
\hline
\end{tabular}

Sumber Harapan Village, annual report on 2017

Based on the data on the list of 1 above, shows that the total number of the woven fabric craftmans in Sumber Harapan village are 277 people, with 432 units of tool. The big number of the weaver are in Semberang village, 146 people at the hamlet of Semberang I. Then, at the hamlet of Semberang hamlet II there are 75 people and the last there are 56 people at the hamlet of Sulur Medan. For the partner which given by the company or institution on 2017 there are 24 people as trainee under PT. Garuda Indonesia and 20 trainee under Dompet Umat Foundation. The Sambas region government had given much help and support, guidance to the people especially give the 
facility and promotion, product marketing in the exhibition, the empowerement, trainings and physical facility like house of woven fabric which has much of effect to the Sambas woven fabric.

Some practical steps in the women empowerement of woven fabric craftsman at Sumber Harapan village which done by the institutions in increasing the people prosperity : 1). Giving the education and training about business, financial and business management ; 2). Giving the mentoring and the capital to the woven fabric craftsman ; 3). Strengthening the contact of personage, cooperation, and good relationship continuosly ; 4). Giving the religious founding to the Sambas woven fabric craftsman in the meeting and recitation of Qur'an weekly or monthly ; 5). Giving the chance to participate in the events in order Sambas woven fabric promotion, whether in the regional area, national and international.

Furthermore, the researcher conducted the strategy analysis in developing of women empowerement to the woven fabric craftsman at Sumber Harapan village,Sambas regency that had been done by SWOT analysis to the condition of Sumber Harapan village. The analysis is done by seeing some factors include the internal and the external using Internal Factor Evaluation Matrix (IFE) and External Factor Evaluation Matrix (EFE). The matrix analysis is done by deeply interview and spreading the polling to the 8 weavers and there are 5 coaches from the region government and Dompet Umat official, and there are 3 academician. So the total polling is spreaded to 16 respondent. The number is represented and can answer the research's problem.

\subsection{The Analysis of IFE Matrix}

The result of analysis of IFE matrix is on list 1.2 The factor that become the main strength of developing the women empowerement to the woven fabric craftsman in Sumber Harapan village, Sambas regency is the skill and the sale value of the woven fabric culture by the scoring is 0.322 . The main weakness is poor in work management belongs to the people in developing economic and also the woven fabric businessman. The main weakness factor in the scoring is 0.210 . The two variables become the things need a serious concern whether it is a strength and the weakness. The mainpoint in developing Sumber Harapan village needs reinforcement and massive promotion in the uniquely of woven culture. However, the management and business management in Sumber Harapan village need more concerns. How and who the business management mechanism must be concerned correctly. For more detail information, it can see in the list below: 


\section{List 2. IFE Matrix The Development of Woven Fabric Craftsman in Sambas regency}

\begin{tabular}{|c|c|c|c|c|}
\hline & Internal Factor & Quality & Rating & Score \\
\hline \multicolumn{5}{|c|}{ The Strength } \\
\hline A & Hardwork & 0.125 & 4.000 & 0.457 \\
\hline $\mathrm{B}$ & Experience & 0.102 & 3.000 & 0.363 \\
\hline $\mathrm{C}$ & The availability of local worker & 0.105 & 3.000 & 0.328 \\
\hline $\mathrm{D}$ & Woven skill & 0.108 & 3.000 & 0.322 \\
\hline \multicolumn{5}{|c|}{ The Weakness } \\
\hline $\mathrm{K}$ & Creativity \& Inovation & 0.082 & 3.000 & 0.341 \\
\hline $\mathrm{L}$ & Information and technology mastery & 0.097 & 3.000 & 0.286 \\
\hline M & The Capital Limitation & 0.086 & 3.000 & 0.206 \\
\hline $\mathrm{N}$ & Management & 0.105 & 2.000 & 0.210 \\
\hline $\mathrm{O}$ & Market Control & 0.102 & 1.000 & 0.126 \\
\hline $\mathrm{P}$ & Business mental & 0.088 & 1.000 & 0.141 \\
\hline & TOTAL & 1.000 & & 2.780 \\
\hline
\end{tabular}

\subsection{The Analysis of EFE Matrix}

The result of EFE matrix analysis is in the factor that become the main strength strategy of developing the women empowerement to woven fabric craftsman is the problem of songket woven fabric UKM that is so easy in availability of the raw materials as much as 0.530 . While the external factor that become the first threat in developing of woven business is the problem of foreign culture influence as much as 0.337 . When it is seen from the opportunity and threat factor. In one side, stated that the development of culture in woven as the main sale value from people's tradition, but in the other side also stated that the incoming of foreign culture is hard to prevent and of course it is worrying will influence the people's culture. 
List 3 . The EFE Matrix in the Developing of Woven Fabric Craftsman in Sambas Regency

\begin{tabular}{lccc}
\hline \multicolumn{1}{c}{ External Factor } & Quality & Rating & Score \\
\hline The opportunity & & & \\
A The availability and woven culture & 0.138 & 4.000 & 0.530 \\
B Share of the market is bigger & 0.119 & 4.000 & 0.517 \\
C Create the new work & 0.115 & 3.000 & 0.347 \\
D The manufacture of modern technology & 0.105 & 3.000 & 0.314 \\
E Big support of government & 0.111 & 2.000 & 0.223 \\
The threat & & & \\
K $\quad$ The Incoming of foreign culture & 0.062 & 3.000 & 0.337 \\
L The market hold by product of other country & 0.079 & 4.000 & 0.175 \\
M Free Trading & 0.108 & 2.000 & 0.213 \\
N The competition & 0.127 & 1.000 & 0.123 \\
O The distribution monopoly by the big company & 0.060 & 1.000 & 0.102 \\
\hline \multicolumn{2}{r}{ TOTAL } & $\mathbf{1 . 0 0 0}$ & $\mathbf{2 . 8 6 0}$ \\
\hline
\end{tabular}

\subsection{The Analysis of Internal-External Matrix}

IFE value is required by the empowerement development of the woven fabric craftsman at Sumber Harapan village is 2,085. While the EFE value is 2,074 (picture 11). The merger of the two values show that the strategy of program development lies at cluster $\mathrm{V}$, in the cell growth strategy. It is an effort of the business growth at woven fabric craftsman in Sambas regency. This strategy emphasize in effort to reaching the growth of business in women craftsman in Sambas regenc like promotion, asset increment (means \& infrastructur manufacture), and profit. The result of merger between IFE and EFE value can be seen as in the picture below :

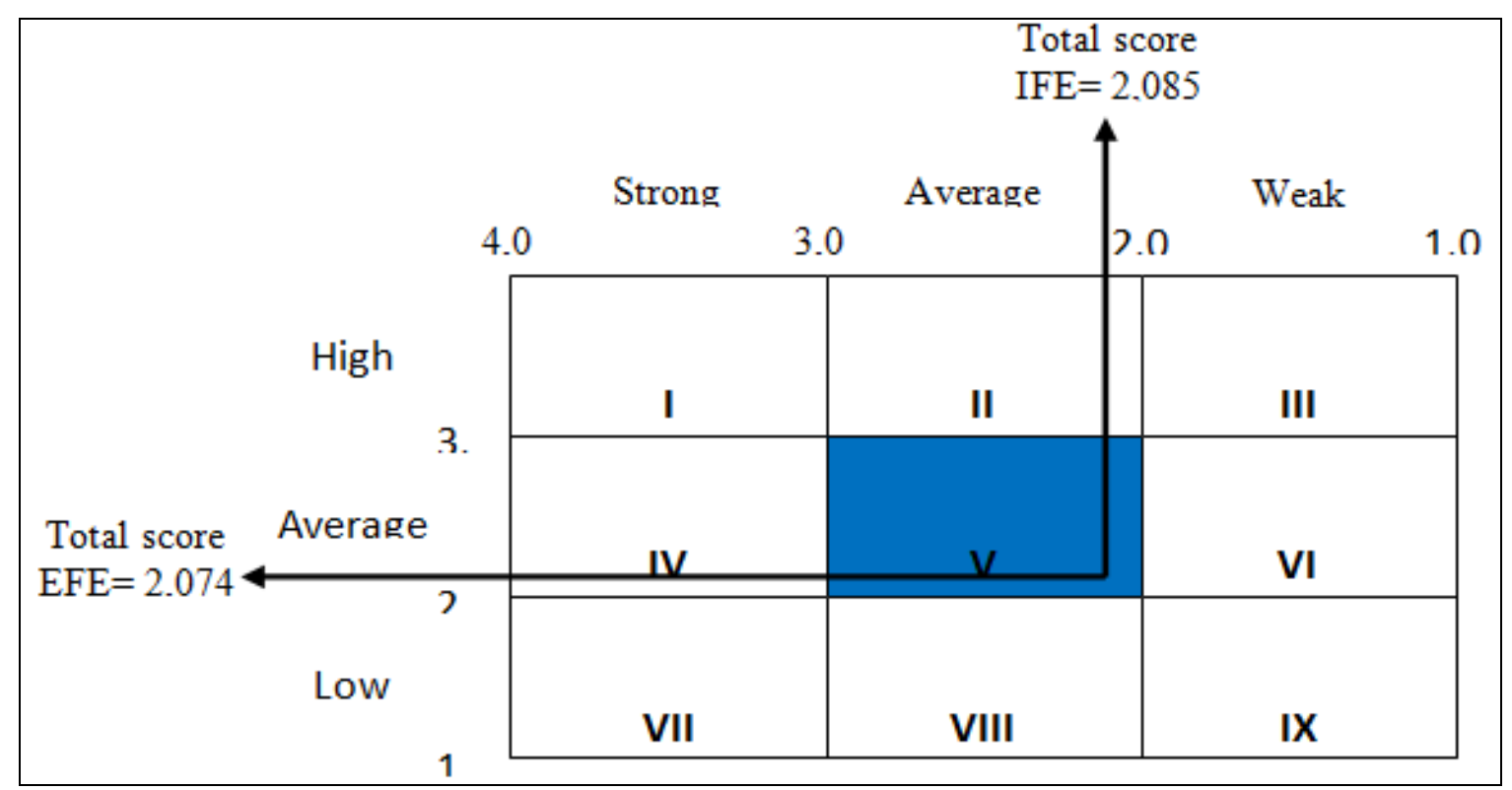




\subsection{SWOT Analysis}

The arranging strategy in SWOT matrix is done appropriate to the result is required from Internal-External Matrix. The position of people economy business activity in the empowerement of woven fabric craftsman in Sambas regency especially in Sumber Harapan village lies in the cell V. Based on the evaluation result of I-E matrix, the SWOT matrix is arranged and then product four types of strategy that can be done, that is S-O, W-O, S-T and W-T. The SWOT analysis result can be seen in the list 4

List 4. SWOT Matrix

\begin{tabular}{|c|c|c|}
\hline $\begin{array}{l}\text { External } \\
\text { Factor }\end{array}$ & $\begin{array}{l}\text { Strength (S) } \\
\text { 1. Hardwork/people character } \\
\text { 2. Business experience } \\
\text { 3. The availability of local } \\
\text { worker } \\
\text { 4. Skill }\end{array}$ & $\begin{array}{l}\text { Weakness (W) } \\
\text { 1. Creativity \& Inovation } \\
\text { 2. Information \& technology } \\
\text { mastery } \\
\text { 3. The capital limitation } \\
\text { 4. Work management } \\
\text { 5. The Market control } \\
\text { 6. Businessman mental }\end{array}$ \\
\hline Opportunity (O) & S-O Strategy & $W-O$ Strategy \\
\hline $\begin{array}{l}\text { 1. Culture availability } \\
\text { 2. Market share is bigger } \\
\text { 3. Create the new business } \\
\text { 4. The Modern of manufacture } \\
\text { technology }\end{array}$ & $\begin{array}{l}\text { a. The usage of experience and } \\
\text { technology for product } \\
\text { intensification and } \\
\text { diversification. }(S 1, S 2, O 1 \text {, } \\
O 2, O 3, O 4, O 5)\end{array}$ & $\begin{array}{l}\text { d. The intregated founding and } \\
\text { human resource development, the } \\
\text { absorption of technology and } \\
\text { information } \\
(W 1, W 2, W 4, O 2, O 3, O 4)\end{array}$ \\
\hline 5. Government support & $\begin{array}{l}\text { b. The utilization of work ethic } \\
\text { to expand the market access } \\
(S 1, S 2, O 1, O 2, O 4, O 5,)\end{array}$ & $\begin{array}{l}\text { e. Take advantage to government } \\
\text { support }(W 1, W 2, W 3, O 3, O 4 . O 5)\end{array}$ \\
\hline $\begin{array}{l}\quad \text { Threat }(\mathrm{T}) \\
\text { 1. Foreign culture } \\
\text { 2. Market control } \\
\text { 3. Free Trading } \\
\text { 4. The competition among the } \\
\text { UKM } \\
\text { 5. Distribution monopoly by } \\
\text { big company }\end{array}$ & $\begin{array}{c}\text { S-T Strategy } \\
\text { c. Increasing the work culture } \\
(S 1, S 2, T 2, T 3, T 4)\end{array}$ & $\begin{array}{cc}W-T \text { Strategy } \\
f . \quad \text { Increasing the cooperation } \\
(W 2, W 3, W 4, T 1, T 2, T 3, T 4)\end{array}$ \\
\hline
\end{tabular}

The alternative of applied strategy that appeared in SWOT matrix consists of 7 kinds of strategy alternative, that is:

a. The usage of experience and technology for product intensification and diversification (S1,S2,O1,O2,O3,O4,O5).

The strategy of experience and technology usage for intensification and diversification is the merger between strengths-opportunities strategy (S-O). Due to the belonging of experience in effort and availability of technology really support for the activity of product intensification and diversification.

b. The usage of work ethic to expand the market access (S1, S2, O1, O2,O4, O5). Marketing is the last process from the business chain. From an effective marketing so the benefit will get. The shape of marketing that can be done by the craftsman is offering or deliver directly to the retailer or the target consumer, person or company. 
c. Increasing the hardwork culture to control the market (S1,S2,T2,T3,T4).

The strategy to increasing the hardwork culture to control the market is the merger between strength-threats strategy (S-T). Face the market condition that getting open and competitive. The market controlling is the important thing and become the requirements to increase the competitiveness among the businessman.

d. The development and the coaching integrated to increasing the quality of human resources in management, the absorption of information and technology about manufacture and market (W1,W2,W4,O2,O3,O4).

The strategy of development and the coaching integrated to increasing the quality of human resources in management, the absorption of information and technology about manufacture and market is backgrounded by the weakness of inovation and creativity, weak in controlling the information and technology, followed by the weakness access of capital, less in work management, market control and less the business mental. Therefore, the development and the coaching integrated to increasing the quality of human resources is important to do, whether in work management, the businessman mindset about the important of technology in production process and information about the market of production result. It is can be done in many ways:

1. Intensifies the trainings to the craftsman.

2. The development of information system to the woven business.

e. Taking advantage on the government support and the private to strengthen the funding in increasing the means and infrastructure (W1,W2,W3,O3,O4.O5).

Beside that, the other strategy that appear in the merger of weakness-opportunities strategy (W-O) is a strategy take an advantage the government support, especially the region government to strengthen the funding in increasing the means and infrastructure.

f. Increasing the cooperation in the institution (W2,W3,W4, T1,T2,T3,T4)

The strategy is included in weakness-threats (W-T) strategy is increasing the cooperation in the institution. The cooperation in a business is important to do, whether for the businessman, government and the banking.

\section{CONCLUSION}

Women is part of the gender that admitted by Allah Swt. In fact, there are so many suppresion and discrimination to them. Therefore, the actualization of women empowerement reputed as important to diminish the role asymmetry between men and women. The women empowerement in Islam perspective is the effort to make them smart in order to fulfilling all of duties and help family economy.

The women empowerement especially to the muslim woven fabric craftsman at Sumber Harapan village that have been done by many people is the real action in gender actualization in today context that will be able bring the prosperity to the people. These 
are the strategy in reinforce the women empowerement to woven fabric craftsman at Sumber Harapan village, Sambas regency : Increase the product intiensification and diversification; The usage of work ethic to expand the market access ; The development and the coaching integrated to increasing the quality of human resources in management, the absorption of information and technology about manufacture and market; Taking advantage on the government support and the private to strengthen the funding in increasing the means and infrastructure ; Increasing the cooperation in the institution.

\section{BIBLIOGRAPHY}

Abdullah, A. F. (2001). Menjadi Ibu Ideal. Jakarta: Pustaka Al-Kautsar.

Abimanyu, A. (2000). Pemulihan Eekonomi Indonesia dan Pemulihan Ekonomi Ummat. Yogyakarta: Tiara Wacana.

Amin Abdullah, D. (2000). Meretas Jalan Baru Ekonomi Muhammadiyah. Yogyakarta: PT. Tiara Wacana.

Ar-Risalah, D. K. K. T. K. (2005). Panduan Wanita Shalihah. Jakarta: Eska Media.

Basuki, A \& Prasetyo, Y. . (2007). Memusimkan Kemiskinan. Surakarta: Pattiro.

Ch, M. (2010). Isu-Isu Gender Kontemporer dalam Hukum Keluarga. Malang: UIN Press.

Cyril E. Black., Jonathan E. Helmreich., Paul C. Helmreich., Charles P. Issawi., \& A. J. M. (1992). Rebith. United states of Amarica: Westview Press.

Dellyana, S. (2004). Wanita dan Anak di Mata Hukum. Yogyakarta: Liberty.

Haryanto, S. (2012). Peran Aktif Wanita dalam Peningkatan Pendapatan Rumah Tangga Miskin: Studi Kasus Pada Wanita Pemecah Batu di Pucanganak Kecamatan Tugu, Trenggalek. UIN malang.

Ilyas, Y. (1997). Feminisme dalam Kajian Tafsir Al Qur"an Klasik dan Kontemporer. Yogyakarta: Pustaka Pelajar.

Khan, Kamla Bashin \& N. S. (1995). Persoalan Pokok Mengenai Feminisme dan Relevansinya. (1st ed.). Jakarta: Gramedia Pustaka Utama.

Mahmudi, Z. (2009). Sosiologi Fikih Perempuan; Formulasi Dialektis Fikih Perempuan dengan Kondisi Sosial dalam Pandangan Imam Syafi'I. Malang: UIN Press.

Martini, H. N. \& M. (1996). Penelitian Terapan. Yogyakarta: Gajahmada University Press.

Marwanti, S \& Astuti, D. (2012). Model Pemberdayaan Perempuan Miskin melalui Pengembangan Kewirausahaan Keluarga Menuju Ekonomi Kreatif di Kabupaten Karang Anyar. SEPA, 9 (1), 73-92. 
Mubyarto. (1997). Ekonomi Rakyat, Program IDT dan Demokrasi Ekonomi Indonesia. Yogyakarta: Aditya Media.

Nur, Asiya Binti. (2017). Peranan Perempuan dalam Perekonomian Nasional.

Qutub, M. (2001). Islam The Misunderstood Religion. Yogyakarta: Mitra Pustaka.

Rahardjo, M. Dawam. (1999). Islam dan Transformasi Sosial Ekonomi. Yogyakarta: Pustaka Pelajar.

Rangkuti, F. (2003). Analisis SWOT Teknik Membedah Kasus Ekonomi. Jakarta: Gramedia Pustaka Utama.

Sahran, R. (2009). Feminisme dan Gerakan Perempuan Tinjauan Fiqh Mazhab Negara di Indonesia. Musawa, 1 (1), 83-106.

Wolf, N. (1997). Gegar Gender. Yogyakarta: Pustaka Semesta Press. 